\title{
Re-Print Cell Impact: Pathophysiological Mechanism of Sars- Cov-2 in the Olfactory and Gustatory System
}

Juan Esteban Tafur Delgado ${ }^{*}$, Geovanny Jesús Bravo Diz², Katherine Stella Humanes Moreno ${ }^{3}$, Moisés Andrés Lombana Salas ${ }^{4}$, Felipe Antonio Tafur Pérez ${ }^{5}$, John Lorenzo Delgado López

${ }^{1}$ Second-Year Pediatric Resident of The University of Sinú.

${ }^{2}$ General Medical Metropolitana University of Barranquilla.

${ }^{3}$ General Medical University Of Sinú, Montería.

${ }^{4} 5$ th Year Medical Student At The University Of Sucre.

${ }^{5}$ General Medical University Of Sinú, Montería.

${ }^{6}$ General Medical University of Magdalena.

*Corresponding Author: Juan Esteban Tafur Delgado, Second-Year Pediatric Resident of The University of Sinú.

Received Date: 23 July 2021 | Accepted Date: 13 Augusł 2021 | Published Date: 26 August 2021

Citation: J E T Delgado, G J B Diz, K S H Moreno, M A L Salas, F A T Pérez, et al. (2021) Cell Impact: Pathophysiological Mechanism of SarsCov-2 in the Olfactory and Gustatory System. Endocrinology and Disorders. 5(6): DOI:10.31579/2640-1045/082

Copyright: () 2021 Juan Esteban Tafur Delgado, This is an open-access article distributed under the terms of the Creative Commons Attribution License, which permits unrestricted use, distribution, and reproduction in any medium, provided the original author and source are credited.

\begin{abstract}
Smell and taste alterations are very common in patients with COVID 19, even when we are in an asymptomatic phase of the disease, it is reported that up to 80 to $90 \%$ of patients present anosmia and ageusia as a cardinal symptom of the disease. In this manuscript we will mention the alterations and the mode of action of the Sars-cov-2 virus at the level of the nasal and buccal fossae, taking into account the alterations at the cellular level as a result of this, based on current evidence, remembering that it is still unknown. A lot about this disease and the way this virus works.
\end{abstract}

Keywords: sars-cov-2; covid 19; anosmia; ageusia; cells

\section{Introduction}

COVID 19 is a disease caused by the Sars-cov- 2 coronavirus. Both the new virus and the disease were unknown before the outbreak in Wuhan, it produces flu-like symptoms, including fever, cough, dyspnea, myalgia and fatigue. Sudden loss of smell and taste has also been observed [1].

In severe cases of the disease, it is characterized by pneumonia, acute respiratory distress syndrome, sepsis, and septic shock that can lead to death [2].

In the list of symptoms in COVID-19, as already mentioned, a sudden loss of the sense of smell and taste has been identified, which at this time is recognized as a cardinal symptom that can be found even in the absence of the others. common symptoms, such as fever, cough, and shortness of breath [3].

In this review we will describe the cellular mechanism by which the loss of smell and taste occurs, based on current hypotheses to explain the pathophysiology of anosmia and ageusia.

Material and Methods
An extensive bibliographic review was carried out where the databases of the National Center for Medical Sciences Information (Infomed) and the websites of the World Health Organization were consulted. In addition, information was collected from articles from national and international journals in databases such as Pubmed / Medline, SciELO, Scopus and other open access journals. Google Scholar and Science Science were used as search engines and the most recently published literature in accordance with the presentation of anosmia and ageusia in this disease was considered as selection criteria. Materials that were in English and Spanish were selected, from that review a total of 10 bibliographic references were used.

Search strategies were applied using the health science descriptors "coronavirus", "COVID-19", "anosmia", "ageusia", and their English equivalents. The quality, reliability and methodological validity of the selected articles were analyzed to carry out an adequate review.

\section{Results}

Angiotensin-converting enzyme 2 has been proposed as the main entry receptor for SARS-CoV-2, since it interacts with the peak proteins present in it. The spike protein allows entry into the host cell through a fusion 
domain, this fusion domain is discovered after maturation of the spike protein by both ACE2 and transmembrane serine protease 2. These proteins are responsible for directing cellular sensitivity to SARS-CoV-2 [4].

Both proteins are expressed mostly in the upper part of the respiratory tract and the greatest amount of these proteins is found in the olfactory epithelium, where the support cells are responsible for expressing most of it. Based on this expression profile, support cells appear to be the main target of SARS-CoV-2 at the level of the olfactory epithelium [5].

In general, most of the data show that the main targets of SARS-CoV-2 at the level of the olfactory epithelium are the support cells. After infection, most of the olfactory epithelium seems to go through a period of desquamation, as indicated by the presence of cellular debris in the lumen of the nasal cavity according to numerous studies (6). This desquamation will eliminate part of the population of olfactory sensory neurons, but it could also be accompanied by a loss of the dendritic layer of these neurons, right in the place where olfactory transduction occurs. These two consequences of the SARS-CoV-2 infection could explain the anosmia observed in the patient with COVID-19. In healthy individuals, recovery would be rapid because the basal cells regenerate the olfactory epithelium [7].

On the other hand, ageusia induced by Sars-cov- 2 could be explained by damage to the taste nerves after a central nervous system infection caused by Sars-cov-2. Although it seems unlikely, since a recent study carried out in humans indicates that the deficiencies of the chemical senses are correlated with low severity in patients with COVID-19 and the prevalence of damage at the level of the central nervous system is low [8].

\section{Discussion}

According to recent studies, loss of smell subjectively affects around 23.7 and $85.6 \%$ of COVID-19 patients, with 11.8 and $73 \%$ of patients being the first symptom. According to the most recent studies, some of them still in the publication phase, it would objectively affect between 50 and $70 \%$ of patients. While the alteration of taste may affect between 35 and $88 \%$ [9].

In Italy, Vaira et al. reported an anosmia rate of 19.4\% in 320 COVID-19 cases [10].

In the United States, Yan et al. included a total of 1,480 patients with influenza-like symptoms who underwent PCR for SARS-CoV-2. Loss of smell and taste was reported in $68 \%$ and $71 \%$, respectively, of COVID19 positive patients [10].
In conclusion, both anosmia and ageusia seem to be one of the main symptoms presented by people infected with sars-cov-2, which could be explained through alterations in the central nervous system and the binding of the virus to the receptors of angiotensin-converting enzyme 2, however, remain hypotheses, which must be tested throughout this pandemic.

\section{References}

1. Pérez, L. C. V. (2020). La COVID-19: reto para la ciencia mundial. Anales de la Academia de Ciencias de Cuba. 10(2), 763.

2. Barón-Sánchez, J., Santiago, C., Goizueta-San Martín, G., Arca, R., \& Fernández, R. (2020). Afectación del sentido del olfato y el gusto en la enfermedad leve por coronavirus (COVID-19) en pacientes españoles. Neurología. 35(9), 633-638.

3. Izquierdo-Domínguez A, Rojas-Lechuga M. J., Mullol J., \& Alobid, I. (2020). Pérdida del sentido del olfato durante la pandemia COVID-19. Medicina Clínica. 155(9), 403.

4. Ninchritz-Becerra E, Soriano-Reixach M M, mayo-Yánez M, Calvo-Henríquez C, de Apodaca P. M. R, Saga-Gutiérrez C, \& Chiesa-Estomba C. M. (2021). Evaluación subjetiva de las alteraciones del olfato y del gusto en pacientes con afectación leve por COVID-19 en España. Medicina Clínica. 156(2), 61-64.

5. Pizarro, S. M. (2020). Impacto de la COVID-19 en Otorrinolaringología. Revista Cubana de Otorrinolaringología y Cirugía de Cabeza y Cuello. 4(3).

6. Waizel-Haiat, S., \& Waizel-Bucay, J. (2021). La pérdida del olfato, un indicador preliminar de COVID-19. Revista Médica del Instituto Mexicano del Seguro Social. 59(1), 4-6.

7. Chávez R. A. M, \& Arroyo A. G. C. (2021). Pérdida de olfato como indicador temprano de infeción por Covid-19. Milenaria, Ciencia y arte. (17). 3-5.

8. Christian Renzo, A. C. (2020). La ageusia como posible síntoma de pacientes con COVID-19. Revista Cubana de Estomatología. 57(3).

9. Alessandro L, Appiani F, Bendersky M, Guerrero, B. B, Bruera G, Cairola P. \& Zalazar, G. (2021). Registro Argentino de manifestaciones neurológicas por coronavirus-19 (COVID-19). Neurología Argentina. 13(2), 84-94.

10. García-Pérez A, Sánchez-Figueras Y, Hernández-Navarro M. I, Sánchez-García A. J, \& Sánchez-García, F. (2021). Disfunciones quimiosensoriales del olfato y el gusto provocadas por el SARSCoV-2. Revista Información Científica. 100(2).
This work is licensed under Creative Commons Attribution 4.0 License
Ready to submit your research? Choose Auctores and benefit from:

*ast, convenient online submission
*igorous peer review by experienced research in your field
*apid publication on acceptance
* authors retain copyrights
* imique DOI for all articles
immediate, unrestricted online access

At Auctores, research is always in progress.

Learn more www.auctoresonline.org/journals/endocrinology-anddisorders 